\title{
THE PROBLEM OF THE POLITICAL AND FISCAL DECENTRALIZATION OF THE LOCAL GOVERNMENT IN 2012-2019
}

\section{ANA TSITLIDZE}

PhD Student

Ivane Javakhishvili Tbilisi State University, Georgia

annatsitlidze@gmail.com

\section{KEYWORDS: LOCAL GOVERNMENT, FISCAL DECENTRALIZATION, EUROPEAN CHARTER, REGIONAL DEVELOPMENT,} SOCIO-ECONOMIC ASPECTS.

For citation: Tsitlidze A. (2019), The Problem Of The Political And Fiscal Decentralization Of The Local Government In 20122019, Globalization And Business, №7, pp. 148-154. https://doi.org/10.35945/gb.2019.07.018

\section{INTRODUCTION}

For every democratic state where a long-term democratic experience exists, a strong local government is fundamental. The local government or the bottom-up rule implies the political, fiscal, and administrative decentralization or devolution of authorities which are closer to people and which, unlike the center, know their needs.

The concept of "decentralization" implies a system of government where some functions of the central authority are devolved on the authorities of the local government (Sikander 2015: 172)

In decentralization, certain issues are devolved on the local population, which deals with those issues independently. This in itself does not mean that the issues of local importance are isolated from the issues belonging to state governance. The fundamental goal of the decentralization is the guarantee and encouragement of the independent initiative (Qurashvili 2003: 3-4).

For the perfect implementation of the decentralization of the local government, the combined and complex work of all types of decentralization is important.

The fiscal decentralization of the local government involves authorizing local governmental bodies to allocate budgets and introduce taxes.

The administrative decentralization of the local government involves the devolution of large powers onto local governmental bodies in the municipal territory, including powers in the management of state affairs and the sphere of public service (Oslen 2007: 5)

The actual political and fiscal decentralization of local government is an important challenge for Georgia, which is on its way to developing democracy and European integration, and which is facing the problems of territorial integrity and of developing a democratic state in the face of the danger of the monopolization of power. Its feasibility and effectiveness define the quality of democracy in the state.

The goal of the article: Study of the political and fiscal decentralization of the local government in Georgia in 20122019. Whether the tentative reformation was realized and what kind of resistance is coming in the way of implementation of the political and fiscal decentralization.

The objectives are:

- The study of the problem of the political and fiscal decentralization of the local government in 1991-2003;

- The problem of the political and fiscal decentralization of the local government in 2003-2012;

- The study of the problem of the political and fiscal decentralization of the local government in 2012-2019; whether the reformation was realized;

- Designing the outcomes and recommendations. 
In writing the article, the following research methods were employed:

Systematic method - the essence and the current process of the political and fiscal decentralization of the local government were analyzed following the approach of structural functioning.

Comparative research method - according to the political and fiscal decentralization of the local government, different authors' points of view and scientific investigations were compared.

Normative research method - this method was used for analyzing and evaluating the political occurrences of the political and fiscal decentralization of the local government, as well as defining the problem facing the process of the political and fiscal decentralization of the local government.

Qualitative research method - in-depth interview. Based on in-depth interviews, the evaluation by local governmental experts, non-governmental organizations, and local actors is especially valuable for the research because the problem of the political and fiscal decentralization of the local government in Georgia in 2012-2019 was seen by the practical outlook and first-hand. The implementation of the stages of reformation was evaluated in the contemporary period.

Sphere of outcome application - the article is the part of the research project "The problem of the Political decentralization of Georgia in 2012-2019 and Baltic Experience"

The outcome, based on the qualitative and quantitative research methods, will be an academic novelty for scholars and scientists about the model of the local government in modern-day Georgia, whether the reformation was held and what should be done for the perfect implementation of political and fiscal decentralization.

The second important period of the political and fiscal decentralization of the local government is connected to the period of 1992-2003, when the political union Citizens' Union, headed by Eduard Shevardnadze, came to the authorities. Civil confrontation, ethnic problems, wars in Abkhazia and Samachablo, Russian aggression, heavy socioeconomic issues in the country and the corruption in state bodies did not leave space for the development of political decentralization of the local government.

Despite these facts, in this period an important legal base (in 1997, the organic law "About Local rule and Government" was enacted) was more or less created for the local government in 1998. The representative bodies of the local government - assemblies elected by the municipal election - were created, and thus the mechanisms of the citizens' participation in the local governmental activity were defined.
The membership of the elected assemblies was characterized by pluralism. The entitlement of the local governmental bodies could not be implemented without their dependency on the central government. Territorial units were controlled by state representative-governors in regions first appointed by the Head of State, and then the president of Georgia; in municipalities, the units were controlled by the heads of local administration. The recognition of the local government and the importance of its decentralization was low not only for citizens but also for political parties and elected officials. Even the heavy socio-economic background prevented the implementation of fiscal decentralization. The governments had neither finances, property, nor ability.

Despite the frequent reformations held and steps taken forward, even the new authorities that came after the "Rose Revolution" cannot avoid the centralized tendency of the local governmental bodies. The political crisis in 2007 and the Russian aggression in Georgia in 2008 slowed the process of the political decentralization of the local government even more, even though in this period, in certain regions, some important socio-economic projects were initiated which were vitally important for the local government and regional economic development.

In Georgia, changing the authorities after the parliamentary election in 2012 led to a proposal for the implementation of reformation of the local government to be once more on the agenda.

The expectation was high that the coalition "Georgian Dream - Democratic Georgia", who came to the authorities in a majority in 2012, would express real political will for the implementation of the political and fiscal decentralization of the local government. The "Georgian Dream" leaders' political announcement before and after coming to authorities in the first years gave the basis for this. Besides the political announcements, from 2013, an intensive and large-scale work began on the local governmental reformation, and two stages of the implementation of reformation were announced: from 2014 to 2017 and then after 2017.

During the first stage of the reformation, the new local governmental code was enacted, the number of selfgoverned cities increased, and local governments were given a lot of authority. The announced reformation would have created a firm basis for the implementation of the political and fiscal decentralization of local governments.

Despite the fact that the reformation had a lot of opponents, the processes begun in 2013 is a step forward for the political and fiscal decentralization of the local government because new self-governing cities were created and local governmental bodies were given a lot of authority which had belonged to the central authorities. The necessity 
of assigning local property to self-government, leaving income tax to the local budget, was defined by legislation, and the code of the local government was enacted, which put together the legal norms of the local government. The code set out the direct path to election of the first person (the head of local administration/mayor) of the local government and the additional mechanisms for citizens' participation in local governmental bodies.

It was important that the local authorities could implement this authority independently in real life and how much the central authorities' will would be enough to accomplish the reformation of the local government in order to give real effective independence to the local government.

Unfortunately the political reality is totally different. Despite the increasing in the authority of local governmental bodies, even after nearly 30 years of independence, both central authorities and the political elite cannot abandon the Soviet practice of the local authority control. The local government elected directly by the people does not have enough political courage to be accountable to the electorate and not to the central authorities or their presenters - political parties. In fact, the informal control of local governmental bodies by the central authorities has not changed. Citizens' lack of participation and interest compound the situation. Oftentimes, the local authorities put the central authorities' will higher than the population's interest, which makes the process of political decentralization impossible, and which makes the population feel that nothing will change at the lower level.

The feeling that the political and fiscal decentralization of the local government was hindered by the authorities' political will become especially clear once again at the second stage of the announced reformation. In 2016, in their implemented reformation, for the purpose of finding and correcting mistakes, the authority eliminated the self-governing status of the seven self-governed cities established in 2014.

It is noteworthy that in spite of the internal resistance of majority members of the self-governed city assemblies against the elimination of self-governing status, the assemblies adopted the decision with the interference of the central authorities. The issue of property transfer to the local government has not yet begun.

The preparation of yet another stage of the selfgovernment reformation was begun by the Georgian authority in 2018. The Georgian government presented a new national vision of decentralization and local government. According to the initiative, the strategy, which should be ready at the end of the year, ensures the strengthening of local governments as well as societies' active inclusion in the process.

The new vision of the local government, or a middleterm strategy, will be scheduled for eight years.
It is known that the authority has a new vision about the local government, but nothing much was said about what this vision involves. It became known to the society that the new national vision of the decentralization and local government elaborated by Georgian parliament and government gives more possibilities to local authority both in decision-making and controlling financial resources. According to the notice by former Prime Minister of Georgia Giorgi Kvirikashvili, "The first, it is the expansion of self-governmental authority. The second is that self-government should have more financial resources for more efficiency. And the third, selfgovernment should satisfy the highest principles of clarity and accountability. It should ensure the citizens' inclusion in the decision making process, management process, and of course, the unity of all three axes will give us a totally different qualitative outcome in self-government (Kvirikashvili 2018).

Despite the last years' changes, experts focus on the current lacunae in the local government, including the financial part and the hindrance of decentralization, the problem of income taxes, ceasing the process of transferring the farming land and local property to the self-government, and the confines of independence and discretion of the local government. According to local government expert Irakli Melashvili, more authority should be given to the local authority both in the decision-making process and in controlling finances, and this vision should be reflected in the strategy announced by the government (Melashvili 2018).

The fact that transferring more authority, including financial issues, to local governments is hindered by the political will of the authorities is also discussed by the head of "International Center for Civil Culture "Kote Kandelaki". According to him, "At this stage, one of the most important points is fiscal decentralization, or more resources and finances on site. It involves both finances and drawing distinctions between the property of central authorities and local government. The local government should feel that they control the property and finances and consequently, they should be given incentives to facilitate local development. Nowadays, the self-governments do not have any incentives to work more in order to get more income, because whatever steps they make, their incomes, unfortunately, do not increase, and first and foremost, this is the error of the legislative base" (Kandelaki 2018).

It is noteworthy that according to Article 162 of "The Code of Local Government", the Ministry of Justice of Georgia, the Ministry of Regional Development and Infrastructure of Georgia, the Ministry of Economics and Sustainable Developments of Georgia and the Ministry of Finances of Georgia should have designed appropriate schedules and rules designating terms of the transfer of farming land to 
municipalities, though this obligation has not yet been carried out, which hinders the process of decentralization of the authorities (Transparency International Georgia 2018).

It has already been half a year that the Ministry of Infrastructure has been trying to decide when they should begin transferring local property to the self-governments They have no answer yet, and nor does the Ministry of Economics. According to an announcement by the Minister of Economics, "This is the current process, and we will always transfer property to the self-government when it is appropriate" (Kobulia 2019). This announcement by the Minister of Economics indicates once more that the authorities do not know yet whether they want to implement political decentralization and to strengthen local governments.

The elected placeholders of the local government talk about the necessity of political and fiscal decentralization of the local government, who think that non-implementation of the fiscal decentralization up today is directly connected to the problem of the political decentralization; it hinders the process of the decentralization and makes inefficient the activity of local governments. The chairperson of Khelvachauri assembly, Nadim Vashanidze, thinks that besides fiscal decentralization, educational decentralization is also important, and that municipalities should have the right to allocate natural resources - otherwise, elected mayors and assemblies lose their meaning (Vashanidze 2018). During the discussion of the strategy of decentralization, elected persons from different municipalities expressed the same position. According to the talk given by the mayor of Shuakhevi municipality, Pridon Putkaradze, the strategy is good but will not help us if we do not step forward effectively" (Putkaradze 2018). According to an announcement by the chairperson of Zugdidi assembly, Mamuka Tsotseria, in many cases, the municipality is encumbered because many authorities that should belong to the municipality belong to the Ministry of Economics, and communication with the Ministry is problematic. According to him, the municipality attempted to implement the registration of some property, though because of lack of finances the task could not be completed. Transferring the property was always the problem for the Ministry of Economics. What is already transferred to us in the case of an investor's appearance, we do not have a mean for its realization or privatization, in the event of the implementation of a strategic plan, only the capital city has the direct disposing for transferring in symbolic price. Local governments should have these rights. Farming lands should belong to the municipality as well. The fact that the Ministry of Economics sells lands discretely reflects on agriculture (Tsotseria 2019).

Representatives of non-governmental organizations and experts announce that the strategy should define clearly the issues of transferring property to self-governments. Besides this, it should be scheduled in the next two-year action plan the terms of which category of lands will be transferred from the National Agency of State Property of the Ministry of Economics to the property of the municipality (Shamugia 2019).

\section{CONCLUSION}

Thus, the process of the political decentralization of the local government has been proceeding inconsistently since 2012. Despite the twice announced and implemented reformation of political and fiscal decentralization of the local government, the problems are unchanged.

- Political powers at the top of the country do not concede the mechanisms of controlling the local governmental bodies;

- Municipalities do not have enough money or authority;

- On the one hand, the autonomy of the implementation of their authority by the self-government is recognized, but, on the other hand, in the realization this right, discretion is maximally restricted;

- The majority of financial resources is concentrated in the hands of the central authorities;

- Municipalities use their poor means inefficiently;

- The informal role of the central authorities is great in the activity of the elected persons and in the process of decision making; elected assembly members and officials depend on the central government.

- The informal role of law enforcement bodies - State Security Service and Ministry of Internal Affairs - is great on the local governmental bodies;

- Regional advisory councils are weak and inefficient whose members are elective persons of the municipality, whereas a person commissioned by the central authorities - the State Representative-Governor heads it. The decisions made by the council are recommendative in nature.

- The State Representative Institute commissioned by the mayor is inefficient at the lower level. This institute becomes a party's agitator in the election process;

- Public meetings and advisory councils work formally; public meetings gather because the legislation requires them. The practice shows us that the citizens faithful to the village representative-ruler's power are often asked for their participation in public meetings. The advisory council of the mayor works formally and inefficiently. The persons faithful to the ruler's power are often appointed the members of the council;

- Despite the fact that one of the authority's arguments was the decrease of bureaucratic expenses regarding 
the implemented changes in the local government and the unification of municipalities, nothing of the sort has happened. On the contrary, after the unification of two municipalities, the bureaucratic expenses stayed the same or increased. Public officers working in local government are mainly appointed according to party line and the announced completion is formal. There is an especially bad situation in Non-enterpreneurial (Non-commercial) Legal Entities of Municipalities;

- Despite the considerable controversies, transferring property to municipalities has not yet begun;

- The still weak political parties developing institutionally are problematic in view of the political decentralization of the local government.

\section{RECOMMENDATIONS}

1. The essence of the theoretical basis of the selfgovernment should be established on the elements of dualistic and state theory, according to which self-government is the unity of both general and state elements. Self-government as bottom-up management and the government closest to the population provides the democratic standard of management and is the main support of democracy;

2. In the transitional period of reformation, a mixed system can be used, but at the end, it is important to achieve the Anglo-Saxon system;

3. The basic principle of the political decentralization of self-government is discretion and independence in the process of making decisions. This is not possible by merely making a distinction between authorities and giving power.
The existence of political will and independence from the party's ambition are necessary;

4. Finishing and defining the administrative-territorial reformation are necessary;

5. Strengthening the role of the representative body the assembly - of which the executor can be a non-elective person. A Baltic model can be used;

6. Together with the elected member of the assembly, it is important that a lower level village representative should be elected, which will assist in the depoliticization of the representative institute; the Baltic model can be followed for the election of the lower level circle. For example, in Lithuania, Slautinis are elected. They do not have their own budget but have an expenditure account;

7. The implementation of fiscal decentralization and transferring of the local property to municipalities;

8. The issues of the regional arrangement - the existing regional advisory councils are inefficient. Besides its inefficiency, a person appointed by the authorities heads it. For political decentralization, it is important that the head of the regional council should be appointed out of the leading persons of the municipality by the council membership with the fixed period. It will decrease the informal control of the activity of the local government by the central authorities;

9. The depoliticization of the Ministry of Internal Affairs and the State Security Service is necessary. The practice showed us that the interference of two law enforcement bodies into the activity of the local governmental bodies has been great, especially in the last years;

10. It is important that the political parties should care about internal democratic development and the growth and develop local leaders.

\section{REFERENCES:}

1. Adalashvili, G. 2013. The reformation of the self-government which should strengthen the city and village. Tbilisi: Radio Independence. Pages 10-15 (in Georgian)

2. Alapishvili, L. 2015. The Self-governmental System in Tbilisi in 1991-2012. In The Rapportof the development of the local Democracy. Tbilisi: The International Center for the Civil Culture. Page 25 (in Georgian)

3. Bedianashvili, G. (1995). State, Power Structure and Socio-Economic Reform of Society. Tbilisi, Mecniereba

4. Chokheli, E., Narmania, D. 2017. On some issues of local self-government in Georgia. International Scientific Conference: Challenges of Globalization in Economics and Business. Conference Papers. Tbilisi

5. Georgian Young Lawyers' Association, Open Society - Georgia Foundation, International Society for Fair Elections and Democracy. 2017. Research: The reformation in the name of the self-government against the self-government. Tbilisi

6. Kandelaki, K. 2018. The Strategy of Decentralization in 2019-2025. www.droa.ge - last checked 10.03.2019

7. Kikvadze, O., Gersamia, M. 2014. The International Legislation of the Local Government, International Organizations and Self-governments. Tbilisi: The Guide of the Clarification of the Self-government. Page 7

8. Kobulia, G. 2018. The Strategy of decentralization in 2019-2025. www.droa.ge-last checked 10.03.2019 
9. Kvirikashvili, G. 2018. The Strategy of Decentralization in 2019-2025. www.droa.ge- last checked 10.03.2019

10. Losaberidze, D. 2015. The Reformation of the Local Government in Georgia in 2013-2014. In The Rapportof the development of the local Democracy. Tbilisi: The International Center for the Civil Culture. Page 20

11. Melashvili, I. 2018. The Strategy of Decentralization in 2019-2025. www.droa.ge-last checked 10.03.2019

12. Nakashidze, N. 2019. The Ruined Property and the Propertyless Self-governments left trusted to the Appropriateness of the Government. http://droa.ge/?p=42897- last checked 10.03.2019

13. Oslen, H. 2007. Decentralization and Local Government https://www.eda.admin.ch/dam/deza/en/documents/publikationen/Diverses/167288-decentralisation-local-governance_EN.pdfLast checked 03.03.2019.

14. Putkaradze, P. 2019. The Ruined Property and the Propertyless Self-governments left trusted to the Appropriateness of the Government. http://droa.ge/?p=42897- last checked 10.03.2019

15. Qurashvili, K. 2003. The Issues of the Realization of the Constitutional Principle of the Local Government in Georgia. Jurnal Almanac. N18. Tbilisi

16. Shamugia, E. 2019. The Depth interview.

17. Sikander, T. 2015. A Theoretical framework of Local Government. International Journal of Humanities and Social Sciences. Rawalpindi. Pakistan

18. Transparency International - Georgia. 2014. The new Local Self-Government Code: Overview of the main novelties. Tbilisi

19. Transparency International-Georgia. 2013. Local self-governance reform - A new Challenge for Georgia. Tbilisi

20. Tsotseria, M. 2019. The Ruined Property and the Propertyless Self-governments left trusted to the Appropriateness of the Government. http://droa.ge/?p=42897- last checked 10.03.2019 


\title{
THE PROBLEM OF THE POLITICAL AND FISCAL DECENTRALIZATION OF THE LOCAL GOVERNMENT IN 2012-2019
}

\author{
ANA TSITLIDZE \\ PhD Student \\ Ivane Javakhishvili Tbilisi State University, Georgia \\ annatsitlidze@gmail.com
}

\section{KEYWORDS: LOCAL GOVERNMENT, FISCAL DECENTRALIZATION, EUROPEAN CHARTER, REGIONAL DEVELOPMENT,} SOCIO-ECONOMIC ASPECTS.

For citation: Tsitlidze A. (2019), The Problem Of The Political And Fiscal Decentralization Of The Local Government In 20122019, Globalization And Business, №7, pp. 148-154. https://doi.org/10.35945/gb.2019.07.018

\section{SUMMARY}

The article contains a concept about Political and fiscal decentralization problem in Georgia during "2012-2019"

For each democratic state strong local government and its political and fiscal decentralization is a fundamental principle of democracy. A local government is a form of public administration which, in a majority of contexts, exists as the lowest tier of administration within a given state. It contains political, fiscal and administration decentralization which means to transfer power from central government to municipality.

In the way of Democracy and European integration as a still democracy development county, Local Government development and its Political and fiscal decentralization is an important and key issues for Georgia.

Aim of the Article: To analyze the process and the problem of Political and Fiscal decentralization of Local Government in Georgia during 2012-2019. What type of problem we have and what is the main problem for Political and Fiscal decentralization of Local Government in Georgia.

Despite all of reforms from independence to nowadays, political and fiscal decentralization of local Government is a problem for all governments in Georgia. The main reason for all of them was political control under the Local governments. After 2012, the hope that the new Government can implement real political da fiscal decentralization of local government was big. But reality is different. Despite two reforms of Local Government during 2012-2019, until now the problem of political and fiscal decentralization in Georgia is the same: no formal control of Local Governments, Most of Financial resources still have central Government, Local Governmnts have no possibility to implement their power independently, they have no own property and suffifient finansial resources.

In this article we give a recommendations how to improve political and fiscal decentralization aspects in Geogria and what the mainc problem is. 